\title{
Improving The Vocabulary Mastery Through Numbered Heads Together Technique of The Seventh Grade Students of SMP N 5 Baturiti In Academic Years 2015/2016
}

\author{
I.D.M.A.W. Sanjaya \\ Jurusan Pendidikan Bahasa Inggris \\ Universitas Pendidikan Ganesha \\ Singaraja, Indonesia \\ e-mail: adhi_fergusen@yahoo.com
}

\begin{abstract}
This study aim at: (1) to find out whether Numbered Heads Together can improve students' vocabulary mastery, (2) to find out the response of the students toward the implementation of the strategies. There were two kinds of data (qualitative and quantitative data) which were collected through tests, questionnaire, and writer's diary. The students' mean score was $4.63 \%$ in pretest, 6.2 in posttest 1 , and improved became 7.97 in posttest 2. There were no students passed in the pretest, 2 students in the posttest 1 , and 18 students in the posttest 2 . The result of writer's diary and questionnaire also showed that the students gave positive response toward the strategies. The results of the questionnaires showed that $18(90 \%)$ of the students admitted that they really like the implementation of Numbered Heads Together. Moreover, 17 (85\%) of the students admitted that they were motivated in learning English using Numbered Heads Together.
\end{abstract}

Keywords: Numbered Heads Together, Vocabulary Mastery

\section{INTRODUCTION}

Today, English is known as an international language. It means that English can be used in communication all over the world. In Indonesia now, English has been one of the subjects that is taught in the school and it has been taught in almost all school levels, start from elementary school to senior high school, and even kindergarten. In learning English, students have to master 4 skills, such as reading, listening, speaking, and writing.

The purpose of English curriculum in junior high school is to equip the students with communicative skills, such as: listening, speaking, reading, and also the writing skill. Besides that, it also aims to introduce the English elements, such as: structure/grammar, vocabulary, pronunciation, and spelling. All of the English skills and elements are really important to be learned by the students in order to have the communicative competence, both in oral and written.

Vocabulary is one of the language components that have to be taught by the teacher of English as a foreign language. Vocabulary is considered to be the most important aspect besides the structure/grammar, pronunciation, and spelling because it will directly contribute to the mastery of the four language skills, namely listening, speaking, reading, and writing. Besides that, the vocabulary itself can give access to widen students' intellectual development. The more vocabulary the students' have, the more knowledge they can understand. In short, it can be said that by enriching the vocabulary, the students will be able to improve their knowledge.

Takac (2008: 4) states that vocabulary can be defined intuitively, as dictionary or a set of words that we teach in foreign language. In learning a foreign language the students have to know what 
words mean. To get the meaning of words, the students should learn vocabulary. There are many ways to present the meaning of new vocabularies to the students such as through illustration, demonstration, translation, and detailed description.

In fact, the English teacher still gets difficulty to determine the most applicable technique of teaching English for children, especially for Junior high school students. The students sometimes get difficulty in memorizing the English vocabulary from time to time. This problem is also faced by the seventh grade students of SMP N 5 Baturiti in academic year 2015/2016 where the study is conducted. After the first data were collected by giving them pre-test inform of multiple choices, the vocabulary mastery of the seventh grade students in this school is quite low.

Many techniques can be applied in teaching vocabulary. One of them is improving the students' vocabulary mastery is through Numbered Heads Together Technique. The research uses this technique because of giving students chance to make up a group or work cooperatively. Moreover, Numbered Heads Together Technique indirectly trains the students to share information to each other. Listening and speaking accurately are also required by this technique that they will be more productive in the teaching learning process. Besides that, this technique also helps the students to be able to work cooperatively in a team or group. Therefore, in accordance with the above facts, the researcher is highly motivated. To improve and find out the effectiveness of Numbered Heads Together Technique in teaching vocabulary and to improve the vocabulary mastery of the seventh grade students of SMP N 5 Baturiti in academic year 2015/2016.

Vocabulary plays an important role in the use of language because in fact it is a basic element that builds up a language, Thornbury (2002:15) states that having an extensive vocabulary means knowing lots of words. At the most basic level, knowing a word involves knowing its form and its meaning. In other words, knowing the meaning of a word does not just about know its dictionary meaning. Zimmerman in Coady and Huckin (1997:5) writes that vocabulary is central to language and critical importance to the language learners. Takac (2008:4) states that vocabulary can be defined intuitively as dictionary or a set of words that we teach in foreign language. and Kamil (2005:3) also broadly define vocabulary as knowledge of words and word meanings. However, vocabulary is more complex than this definition suggests.

Regarding on its importance, Vocabulary has often been viewed as a basic element in language teaching. It is considered to be the most important aspect because it can widen the students' intellectual development. In learning a foreign language the students have to know what words mean. To get the meaning of words, the students should learn vocabulary. Wilkins in Thornbury (2002:13) states that without vocabulary nothing can be conveyed. Most improvement in language will be seen by learning more words. Hiebert and Kamil (2005:2) state that vocabulary holds a special place among the language components. Daller, Milton, and TreffersDaller (2007:1) write that vocabulary is now considered to just about every aspect of language knowledge.

vocabulary mastery is the most important thing in learning language. In order to be able to communicate effectively, the learners should have enough vocabulary on their knowledge. Vocabulary can be developed using different methods and techniques, such as word games, matching picture, guessing words, singing songs, etc. The purpose is to make the material more enjoyable, interesting and challenging.

Richards and Nation in McCarten (2007:18-20) list the different things learners need to know about a word before we can say that they have learned it.

Tomlinson in McCarten (2007: 2021) states that teachers can use different ways to present vocabulary including using pictures, sounds, and different text types with which students can identify: 
stories, conversation, web pages, questionnaires, news, reports, etc. In each of the contexts, the topics should vary and engage students at different levels.

Celce and Murcia (1991: 298-300) mention two kinds of techniques which can be used in the teaching of vocabulary, namely: unplanned vocabulary teaching and planned vocabulary teaching. McCarten (2007:21) writes that learning vocabulary is largely about remembering and students generally need to see, say, and write newly learned words many times before they can be said to have learned them. Moreover, Sokmen in McCarten (2007:21) also states that repetition is an important aid to learn vocabulary. Trianto $(2007: 41)$ states that the students or learners usually find it easier for them to learn something through group work and discussion (cooperative learning).

Traditionally, the teaching of vocabulary was mostly incidental, limited to the presenting new items as they appeared in reading or sometimes listening texts. Trianto (2007:62) states that Numbered Heads Together Technique which was designed by Spencer Kagan in 1993 is a cooperative teaching technique in which the students are involved in analyzing the material discussed in the teaching learning process.

There are four steps in the teaching learning process through numbered heads together technique, they are:

Numbering is the most important step in the teaching learning process through Numbered Heads Together technique. In this step, the teacher divides the students into several groups which consist of 3 to 5 students in each of the groups. All of the students in the groups are given a number based on the quantity of the students in the groups.

The next step is called proposing question. In this step, the teacher proposes a certain question to the students. The question itself can be based on the material which is discussed in the teaching learning process. The question which is proposed should be varied, from the specific question to the general one. Besides that, the question should also be created with difference level of difficulty.

After getting the question from the teacher, all of the students in the group should discuss the answer together. In this step, they can share the information they own with the other members of the group. The point is, all of the students in the group should involve in the discussion to make sure that all of them know the answer.

The last step in the teaching learning process through Numbered Heads Together technique is answering. In this step, the teacher chooses a certain number and all of the students who get the number which is mentioned should present their groups' answer in front of the classroom.

Moreover, Frey, Fisher and Everlove (2009:59) state that in the teaching learning process through Numbered Heads Together Technique, the students are divided into groups and each member is assigned a number. Tileston (2004:85) also states that Numbered Heads Together Technique can be used to see how well the groups had read and discussed the assignment given by the teacher. In addition, Numbered Heads Together technique is an effective way to be used in improving the students' vocabulary mastery. It indirectly trains the students to share information to each other, listen and speak accurately, so that they will be more productive in the teaching learning process.

Assessment is the part of modern life. It can be defined as a way of getting feedback on the teaching-learning process. Brown (2004: 4) states that assessment is an ongoing process that encompasses a much wider domain. Georgiou and Plavou (2003:4) explain that assessment is a general term which includes all methods used to gather information about children's knowledge, ability, understanding, attitudes, and motivation. Georgiou and Plavou (2003: 56) states that assessment may at first sound threatening and not suited to a child's nature, but it is a necessary part of the teaching and learning process. Brown (2004:4-8) specifies four main approaches to language assessment: discrete point, 
integrated testing, performance-based assessment, traditional assessment, communicative language testing.

Brown (2004: 229) states that there are two kinds of the major techniques used to assess vocabulary, namely (a) defining and (b) using a word in a sentence. Moreover, Heaton (1988: 51-62) mentions several instruments to be used in assessing the students' vocabulary mastery, namely multiple-choice test items, associated words items, matching items, and completion items.

There were some researches who conduct the same study about numbered heads together. Prehanta (2014) the best way of improving English vocabulary was using numbered heads together technique, there was a significant effect of using this technique on students' vocabulary achievement at SMP Negeri 2 Kalisat was accepted. There is also an experimental study by Rahmawati (2014) to assess the effectiveness of using cooperative learning type numbered heads together in improving reading comprehension of the student at SMP $\mathrm{N}$ 20 Tangerang.

Darsana (2014) conducted at SMP N 2 sukawati. The study was conducted to improve students in vocabulary mastery. Yukya (2010) also conducted a study using numbered head together technique to improve student's vocabulary mastery in SMP N 1 Ubud. Yukya found that students' mean score on vocabulary mastery in SMP N 1 ubud increased. Danil Baker (2013) was also conducted the Numbered head together technique. As his result numbered head together technique was as effective as individual instruction for all other groups of students. Based on Maharani (2013) Numbered
Heads together gave positive contribution towards the student's vocabulary mastery. It can be seen from the gained before and after the treatment is being given.

Looking at the Numbered Heads Together Technique as conducted by the experts, the strengthens of this technique was able to give the students great mind in applying their ideas when the teaching learning process, and the weakness of this technique was the allocation of time so that its explanation was so limited.

\section{RESEARCH DESIGN}

This study uses Classroom Action Research (CAR) as the research design. Schollaert (2000:56) states that Classroom Action Research was firstly introduced by Stenhouse in 1975 and promoted by Elliot in 1991. This kind of research consists of 4 major phrases, namely Planning (theory formulation), Action (intervention is carried out), Observation (data collection of intervention), and Reflection (data analysis).

The subject of this study is the students of VIIB SMP Negeri 5 Baturiti in the academic year 2015/2016. The subject is chosen based on the preliminary observation that was done by the writer.

This classroom action research is concerned with teaching vocabulary through Numbered Heads Together Technique and is conducted to answer the research question. In this classroom action study, the teaching and learning processes will be divided into two cycles where each cycle consists of four interconnected activities, namely: planning $(P)$, action $(A)$, observation $(\mathrm{O})$, and reflection $(R)$. Obviously, the design of the present classroom action study could be described in the following:

$$
\begin{gathered}
\text { Cycle } 1 \rightarrow \mathrm{PO} \rightarrow \mathrm{P} 1 \rightarrow \mathrm{A} 1 \rightarrow \mathrm{O} 1 \rightarrow \mathrm{R} 1 \\
\text { Cycle } 2 \rightarrow \mathrm{RP} \rightarrow \mathrm{A} 2 \rightarrow \mathrm{O} 2 \rightarrow \mathrm{R} 2
\end{gathered}
$$

Figure 1. The Research Design

Adapted from Ferrance (2000: 1)

Notes:

$\begin{array}{ll}\text { PO } & \text { : preliminary Observation } \\ \text { P } & \text { : Planning } \\ \text { A } & \text { : Action } \\ \mathrm{O} & \text { : Observation }\end{array}$




\section{R : Reflection \\ RP : Revised Planning}

Based on that explanation, the outcome of the reflection or post-tests in cycle I will be used as valuable input and a basis to accordingly revise the planning in cycle II. Therefore, cycle II which begin with revised planning (RP) was predictably much more successful and conductive then cycle I. The completeness at concerning the activities carried out in each session from $P, A, O$, and $R$ is dedicated to the subsequent discussions and for details of lesson plan for the present classroom action study.

The writer conducted a preliminary observation to obtain the data about the students' vocabulary mastery at the beginning of doing research. The data which were obtained from the preliminary observation will be used design the cycle 1 in the action-based research which includes planning, action, observation/evaluation, and reflection.

\section{Planning}

Planning first step that the writer should do in each cycle. It used to create and determine the treatment that was applied in each cycle, the procedures of the action, and instruments needed in collecting the data.

\section{Action}

In action stage, the writer started to apply the technique that was planned in planning stage. Action dealt with what the writer does in the classroom and how the class managed based on the teaching and learning scenario that had been planned.

\section{Observation}

Observation is the activity of observing the classroom during the lesson to assess the achievement of the objective and the process of teaching and learning in the classroom. It covered students' response toward the implementation of the technique that was being applied or the students' behavior during the teaching and learning process.

\section{Reflection}

Reflection is the activity of reflecting and analyzing the action done at the end of each cycle. It came from the result of observation which showed the strengths and weaknesses of the action. From the reflection, the writer could decide whether or not the cycle could be continued.

To collect the data, there were three types of instruments used in this study, namely: tests (Pre-test and Post-tests), the writer's diary, and questionnaire. There were two kinds of tests used in this study. Those are (1) pre-test which was used to identify the students' problem in writing, (2) post test which was administered in the end of each cycle. The Post-test would reveal the degree of success of the technique.

The questionnaire was handed in the end of each cycle to find out the response of VIIB class students of the SMP Negeri 5 Baturiti in the academic year of 2015/2016 to the application of Numbered Heads Together technique in English class. It consisted of 10 items of multiple choices (3 item dealt with students' attitude, 2 items dealt with the role of the treatment towards the students' vocabulary mastery, 3 item dealt with students' motivation, and 2 items dealt with the writer's way in applying the strategy).

After the subjects of the study were chosen, the interview, pre-test and questionnaire were handed to the students to reveal the more specific problem faced by the students.

The cycle 1 was begun by planning the actions, the material and instruments used for collecting the data. It was continued by action where the planning was realised. After that, observation was done to evaluate the teaching and learning process due to the strategies implemented. The last stage in cycle 1 was reflection which was used to analyse the students' problem, the strength and 
the weakness of the instruction, and the solution for the problems. The activities for the next cycle would also be determined at this phase by modifying the parts of action causing problem.

The data used in thi study were in form of quantitative and qualitative data. The quantitative data were obtained from pre-tests and posttest. The quantitative data were analyzed descriptively. The students' mean score in the pre-test were compared with the mean score in the posttest in order to know the students' improvement in vocabulary mastery. The mean score of the students would be used as the indicator of this study. The formula is as follows:

$$
X=\frac{\sum Y}{n}
$$

The students' mean score would be categorized into some level. The table below is the criteria used to determine students' level in writing which was adapted from Prihanta (2014)

Table 1. The students' Vocabulary Mastery level criteria

\begin{tabular}{cc}
\hline Scores & Level of mastery \\
\hline $95 \%-100 \%$ & Excellent \\
\hline $85 \%-94 \%$ & Very Good \\
\hline $75 \%-84 \%$ & Good \\
\hline $65 \%-74 \%$ & Moderate \\
\hline $0 \%-64 \%$ & Poor \\
\hline
\end{tabular}

Meanwhile Qualitative data were obtained from the results of questionnaires and writer's diary. The writer's diary was analyzed directly from what the writer recorded during the class. The evidences which were found in writer's diary became the basis of the analysis from the test and questionnaire.

The results of questionnaire which dealt with the students' responses toward Numbered Heads Together technique were analyzed descriptively, The percentage of the questionnaire's result was calculated using the following formula:

$$
\%=\frac{\text { Number of items chosen by the students } \times 100 \%}{\text { Total number of the students }}
$$

According to BSNP (2006), a learning process will be considered as successful if $\geq 85 \%$ of the students pass the target score. Regarding to BSNP (2006), the study was considered successful and stopped if the class success rate $\geq 85 \%$. It means that $\geq 85 \%$ of the students can obtain the target score, $\geq 75$ of the maximum score. It was based on the line of the passing grade used in the school where the study is conducted.

\section{FINDING AND DISCUSSION}

As the numeric data had been obtained from the score that was gained from pre-test, post-test 1 and post-test 2, the writer presented the comparison of the students' mean score improvement in vocabulary mastery to see how much they improved from every cycle which can be seen through the following table and graph.

Table 2. The Students' Mean Score Improvement

\begin{tabular}{llc}
\hline TEST & MEAN (\%) & CATEGORY \\
\hline Pretest & $4.63 \%$ & Poor \\
\hline Post - Test 1 & $6.2 \%$ & Poor \\
\hline Post - Test 2 & $7.72 \%$ & good \\
\hline
\end{tabular}




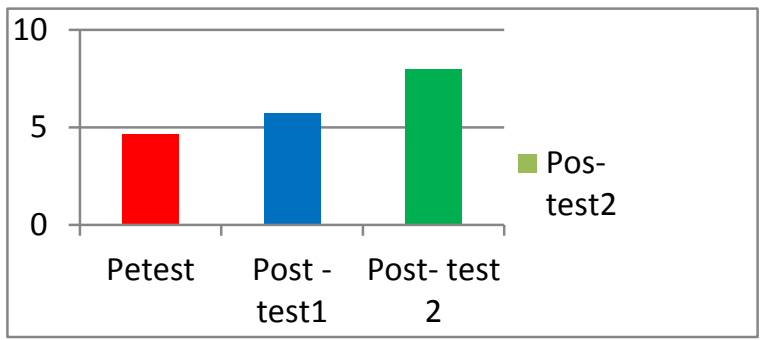

Figure 1. The Students' Mean Score Improvement

The problem faced by the students was identified through the preliminary observation conducted before two cycles were carried out in classroom. The table 4.4 and graph 4.1 show that the result of the Pre-test indicated that the mean score of the students in class VIIB of SMP Negeri 5 Baturiti was moderate. The students' mean score was 4.63 which could be categorized as poor.There were no students who achieved a good level. The mean score was still below the standard passing score of the school in which the maximum score required was 75.

In cycle 1 , the students were given the treatment with Numbered Heads Together technique. The result of the post test 1 showed some improvement in terms of the students' vocabulary mastery. From the result of the Post-test 1 , it was found that $2(10 \%)$ of the students achieved good level of vocabulary mastery, and 5 $(25 \%)$ of the students achieved moderate level of vocabulary mastery. Meanwhile, $13(65 \%)$ of the students was still in poor level of vocabulary mastery. It means that $2(10 \%)$ students had passed the target score of the study as well as the standard passing score applied in the school.However, since the study required $\geq 85 \%$ students to achieve the target score, the writer continued the study by conducting cycle 2 .

The improvement also occurred after the writer gave the treatment on cycle 2 . From the graph 4.1, it can be seen that the students' mean sore was increased $1.77 \%$ from $6.2 \%$ in post test 1 to $7.97 \%$ in post test 2 . It can be categorized as good level. The improvement occurred could not be apart from some modification done in teaching and learning activities in cycle 2 . From 20 students who followed the test,2 $(10 \%)$ of students achieved excellent level,
$3(15 \%)$ of the students achieved very good level, $13(65 \%)$ of the students achieved good level, and $2(10 \%)$ of the students achieved moderate level. There were no students who were in poor level of vocabulary mastery. It means that 18 $(90 \%)$ students had passed the target score of the study as well as the standard passing score applied in the school. Besides, the students' mean score in post test 2 was 7.97 which can be categorized as good. It means that the students' mean score had already met the standard score (75).

\section{The Students' Responses Toward the Implementation of Numbered Heads Together Technique}

Based on the result of the questionnaires in implementing Numbered Heads Together technique that were handed at the end of every cycle, it was found that the students gave positive responses as what can be seen in the result of the questionnaire that was handed in post-test 1 and post-test 2 in which each of the questionnaire consisted of10 items of multiple choices (3 item dealt with students' attitude, 2 items dealt with the role of the treatment towards the students' vocabulary mastery, 3 item dealt with students' motivation, and 2 items dealt with the writer's way in applying the strategy). The result in of the questionnaire showed that the students gave positive responses towards implementation of Numbered Heads Together technique. It means that these strategiescan be accepted well because almost all of students said that they really liked the strategies.

From the questionnaire, it was also found that the students were motivated by the implementation of Numbered Heads Together technique. The students implied 
that they liked the way the writer gave them project task because it was very challenging. The students also implied that they can understand the lesson from the summary that was done by the teacher in the end of meeting.

The result of questionnaire showed that the students loved the task given because it was very relevant to their level. This was the benefits of Numbered Heads Together technique in which the project task can be modified to match the students' level.

There were two objectives in this study. Those wereto improve the students' vocabulary mastery through the Numbered Heads Together technique and to see the students' responses toward the tehnique. After conducting the treatment in two cycles, the purposes of the study were accomplished. The results of this study could not be a part from some strengths and weaknesses in every cycle.

The students' low vocabulary mastery could be solved by the implementation of Numbered Heads Together technique. It was focused on the way how the students could easily remember some new vocabulary by using Numbered Heads Together technique.

\section{CONCLUSION AND SUGGESTION}

From the comparisons of pretest,post test 1 and post test 2 , it can be revealed that the score of vocabulary mastery ofthe students of VIIB class in SMP Negeri 5 Baturiti was successfully improved.Based on the findings and discussion in previous chapter, it can be concluded that the implementation of Numbered Heads Together Technique can improve students' achievement.

Based on the results of the questionnaire and writer's diary in implementing Numbered Heads Together technique, it was found that the students responded that they were highly motivated. The results showed that the students' performance during the treatment was improved. The students were really motivated by the implementation of Numbered Heads Together technique because it was very challenging and interesting therefore they loved to involve in class discussion. They loved the task given because it was really relevant to their level.

\section{REFERENCES}

Brown, H. Douglas. 2004. Language Assessment Principles and Classroom Practices. New York: Pearson Education.

Celce, Marianne and Murcia. 1991. Teaching English as a Second or Foreign Language. Boston: Heinle and Heinle Publishers.

Coady, James and Thomas Huckin. 1997. Second Language Vocabulary Acquisition. Cambridge: $\quad$ Cambridge University Press.

Daller, Helmut and James Milton, 2007. Modeling and Assessing Vocabulary Knowledge. Cambridge: Cambridge University Press.

Danil Baker. 2013. Effective of Numbered Heads Together Technique As Individual Instruction For All Groups Of Students. homepages.lboro.ac.uk. Retrieved 24 February 2015.

Darsana. 2014. Using Numbered Heads Together Technique To Improve Student In Vocabulary Mastery. a multidisciplinary journal, v46 n1 p129 mar 2014. Retrieved june 25, 2015 , from, eric.ed.gov/id=EJ682769

Georgiou, Sophie Joannou andPavlospavlou. 2003. Assessing Young Learners. Oxford: Oxford University Press.

Hiebert, Elfrieda $\mathrm{H}$. and Michael L. Kamil. 2005. Teaching and Learning Vocabulary: Bringing Research to Practice. London: Lawrence Erlbaum Associates, Inc

Maharani. 2013. The effectiveness of Using Numbered Heads Together To Improve Vocabulary Mastery of The 
Fifth Grade Students of SD N KARANGGEDE In The Academic Yeers 2012/2013. Purworejo: Muhamadiyah University of Purworejo:a multidisciplinary journal,v38 n1 p1-30 Jul 2013. Retrieved june 25, 2015, from, eric.ed.gov/id=EJ682769.

McCarten, Jeanne. 2007. Teaching Vocabulary: Lesson from the Corpus; Lessons for the classroom. Cambridge: Cambridge University Press

Prehanta. 2014. The effect Of Using NHT Technique On The Seventh Grade Students' Vocabulary Achievement At SMP Negeri 2 Kalisat In The Academic Years 2013/2014. Jember: UniversitasJember.

Rahmawati. 2014. Cooperative learning type numbered heads together in improving reading comprehension of The Student at SMP N 20 Tanggerang. Journal of Behavioral Education;Sep2014, Vol. 18 Issue 3, p222

Takac, VisnjaPavicic. 2008. Vocabulary Learning Strategies and Foreign Language Acquisition. Bristol: Multilingual Matters Ltd.

Thornbury, Scott. 2002. How to teach Vocabulary. London: Pearson Education Limited.

Tileston, Donna Walker. 2004. What Every Teacher Should Know about Efective Teaching Strategies. Londom:Corwin Press.

Trianto. $2007 . \quad$ Model-Model

PembelajaranInovatifBerorientasiKo nstruktivistik. Jakarta:

PrestasiPustaka.

Yukya. 2010. Numbereh Heads Together Technique To Improve Student's Vocabulary Mastery In SMP $N 1$ Ubud. Ubud: Universitas Mahasaraswati. 